\title{
Does entrepreneurial knowledge influence vocational students' intention? Lessons from Indonesia
}

\author{
Rr Ponco Dewi Karyaningsih, Agus Wibowo, Ari Saptono, Bagus Shandy Narmaditya
}

\section{A B S T R A C T}

Objective: The study attempts to extend the current understanding of entrepreneurship education by engaging the entrepreneurial mindset, knowledge, and the intention to be an entrepreneur. The second purpose is to highlight through testing the moderating role of entrepreneurial knowledge on the relationship between entrepreneurial education and students' intention to be entrepreneurs.

Research Design \& Methods: The approach utilised in this study was a quantitative research design using a survey model. The participants of this study were recruited from vocational students in Jakarta who enrolled in the entrepreneurial education course. Furthermore, the data were analysed using exploratory factor analysis (EFA), confirmatory factor analysis (CFA), and structural equation modelling (SEM).

Findings: Entrepreneurship education impacts three variables, including entrepreneurial mind-set, knowledge, and intention. Entrepreneurial knowledge influences students' intention to be entrepreneurs; however, it has an insignificant impact on entrepreneurial mindset.

Implications \& Recommendations: Entrepreneurship education in Indonesia should be further developed due to its essential role in education young entrepreneurs, for instance, through curriculum revitalisation.

Contribution \& Value Added: Notwithstanding the relatively limited sample, this work offers valuable insights into the important role of entrepreneurship education and vocational students' intention to be entrepreneurs in Indonesia.

\begin{tabular}{|c|c|}
\hline $\begin{array}{l}\text { Article type: } \\
\text { Keywords: }\end{array}$ & $\begin{array}{l}\text { research article } \\
\text { entrepreneurial education; entrepreneurial knowledge; entrepre- } \\
\text { neurial mindset; entrepreneurial intention; vocational school }\end{array}$ \\
\hline IEL codes: & \\
\hline Recei & Accepted: 20 August 2020 \\
\hline
\end{tabular}

\section{Suggested citation:}

Karyaningsih, R.P.D., Wibowo, A., Saptono, A., \& Narmaditya, B.S. (2020). Does entrepreneurial knowledge influences vocational students' intention? Lessons from Indonesia. Entrepreneurial Business and Economics Review, 8(4), 138-155. https://doi.org/10.15678/EBER.2020.080408 


\section{INTRODUCTION}

Over the past decade, the majority of scholars in both developed and developing countries claimed that entrepreneurial education plays a crucial role in motivating entrepreneurs (Jena, 2020; Li \& Wu, 2019; Fayolle \& Gailly, 2015). Moreover, scholars also agree that entrepreneurial education does not only engage students' knowledge, mindset, attitude, and self-efficacy but also develops students' intention and skills to start a business (Kim \& Park, 2019; Barba-Sánchez \& Atienza-Sahuquillo, 2018; Souitaris, Zerbinati, \& Al-Laham, 2007; Zhang, Duysters, \& Cloodt, 2014). Furthermore, some countries propose entrepreneurial education as an effective strategy to enlarge the number of entrepreneurs, particularly through formal education (Nasrullah, Khan \& Khan, 2016; do Paco et al., 2013; Fayolle, 2006).

In Indonesia, the government has sought to increase the number of entrepreneurs by amending entrepreneurial education in all level education (Sendouwa, 2019; Hani \& Putri, 2012; Utami, 2017; Utomo et al., 2019). In higher education, the policymaker focuses on the revitalisation of vocational school curriculum as an attempt to motivate students to become entrepreneurs (Saptono \& Wibowo, 2018; Wibowo, Saptono, \& Suparno, 2018). According to the Ministry of National Education (2012), entrepreneurial education in vocational school is intended to motivate students to become young entrepreneurs instead of middle-level skilled workers.

Unfortunately, the reinvigorated curriculum of entrepreneurial education in the vocational school is not adequate yet. In fact, the unemployment rate in Indonesia is dominated by vocational school graduates (BPS, 2019). In more detail, BPS (2019) notes that the unemployment rate in August 2019 amounted to 7.05 million, dominated by vocational school graduates by approximately $10.42 \%$. This is due to vocational school graduates insufficiently creating their own businesses along with enrolling to work in accordance with the demand of the workforce. This readiness shows that the quality of vocational graduates still must be improved, especially their independence and reasoning.

Furthermore, Husnaini (2017) argues that the upward trend in the unemployment rate is affected by the ineffectiveness of entrepreneurial education in vocational schools. Similarly, Jabeen, Faisal, and Katsioloudes (2017) indicate that entrepreneurial education in the school provides inadequate knowledge and mindset to start a business. However, when entrepreneurial education is applied appropriately, it raises students' intention to be entrepreneurs. Several scholars assert that entrepreneurial education promotes creating individual entrepreneurship (Utomo et al., 2019; \& Block, 2016; Rauch \& Huslink, 2015).

The investigation of entrepreneurial education among Indonesian scholars have rapidly increased (Ana et al., 2016; Eryanto; 2019; Winarno, 2016; Saptono \& Wibowo, 2018; Wibowo et al., 2019). However, few researchers have demonstrated the relationship between entrepreneurial mindset and intention of being entrepreneurs. In fact, both variables have a pivotal role incorporate with entrepreneurial intention (Rezaei Zadeh et al., 2017; Farani et al., 2017; Tshikovhi \& Shambare, 2015). Entrepreneurial knowledge is closely related to several business activities, such as identification, company creation, marketing, finance, and organisation. Students' knowledge of entrepreneurship could be acquired through school education and training (Bergmann, 2017; Ni \& Ye, 2018; Zhao \& Seibert, 2006). These findings suggest that entrepreneurial knowledge and mindset obtained from entrepreneurship education positive influences students' intention to be entrepreneurs. Roxas (2014) adds that 
entrepreneurial knowledge and entrepreneurial mindset play a crucial role in mediating the impact of entrepreneurial education and entrepreneurial intention.

This study provides three contributions. First, it extends the existing understanding of entrepreneurship education by engaging entrepreneurial intention and knowledge, which is absent in prior studies. Through testing, this article highlights the mediating role of entrepreneurial knowledge on the relationship between entrepreneurial education and students' intention to be entrepreneurs. Second, the focus in Indonesia is unique due to the fact that Indonesia is a densely populated country, but it has an insufficient level of entrepreneurs. Third, this study provides new insight into the debate on the factors affecting entrepreneurial intention in Indonesia, and the debate's influence on the policymakers who decide about education.

\section{LITERATURE REVIEW}

The growing body of literature investigating entrepreneurial intention agrees that intention can be formed with some deliberate scenarios (Van Gelderen, Kautonen, \& Fink, 2015; Minola, Criaco, \& Cassia, 2014). Education becomes one of the effective means of developing entrepreneurial intentions (Passoni \& Glavam, 2018; Barba-Sánchez \& Atienza-Sahuquillo, 2018; Küttim et al., 2014). Watson (2019) reveals that entrepreneurship education could stimulate ideas and behaviours needed by an entrepreneur. Ahmed et al. (2020) conclude that the goals of entrepreneurship education are to foster individual entrepreneurial intentions. An empirical study by Saeed et al. (2015) finds that entrepreneurship education and training can strengthen individuals' entrepreneurial intentions and improve their performance.

How does entrepreneurship education improve student entrepreneurial intention? First, entrepreneurial intention in this study covers students' desire to be entrepreneurs and their willingness to set up and run businesses. Wu and $\mathrm{Wu}$ (2008) emphasise that entrepreneurship education focuses on increasing students' entrepreneurial knowledge, willingness, and abilities both through theory and entrepreneurship training. Similarly, Souitaris, Zerbinati, and Al-Laham (2007) and Nabi et al. (2018) foreground how entrepreneurship education influences students' entrepreneurial intentions through learning, inspiration, and the use of resources. Learning in entrepreneurial education helps individuals to obtain knowledge on how to start a new business.

The entrepreneurial education should be provided more practice instead of theories (George \& Bock, 2011). For instance, a social programme allows an individual experience direct application of theory in the field (Dvoulety et al., 2018). This practice model not only stimulates students' interest in studying entrepreneurship but also provides an entrepreneurial attitude (Lackeus, 2014). Some previous studies find a relationship between entrepreneurial education and intentions to be an entrepreneur (Fayolle \& Gailly, 2015; Koe, 2016; Sánchez, 2013; Zhang, Duysters, \& Cloodt, 2014). Likewise, in Indonesia, several scholars demonstrated the positive impact of entrepreneurial education on entrepreneurial intention (Purwana et al., 2019; Saptono et al., 2019; Wibowo et al., 2019).

Furthermore, Fayolle and Gailly (2015) emphasise that entrepreneurship education impacts individual mindset, which guarantees the capacity to acquire entrepreneurial knowledge by helping an individual to focus on a proper career path. An anticipated longterm investment that results from entrepreneurial knowledge is the production of an entrepreneur who permeates one's personal, social, and professional life (Moberg, 2014). Haynie 
et al. (2010) emphasise the strong relationship of entrepreneurial mindset with practical reasoning, entrepreneurial knowledge, and individual competence to obtain valuable resources for business success. Entrepreneurial knowledge covers a proper understanding related of entrepreneurship; e.g. sales, negotiation, product development, and risk assessment.

We believe that entrepreneurial intention and an individual's potential can be increased through entrepreneurship education. In other words, entrepreneurship education can help students to develop entrepreneurial knowledge, skills, mindset, and increase their future success in starting a business. Therefore, we developed the following hypotheses:

H1: Entrepreneurial education positively influences entrepreneurial intention.

H2: Entrepreneurial education positively influences entrepreneurial knowledge.

H3: Entrepreneurial education positively influences entrepreneurial mindset.

Entrepreneurial human capital (EHC) is a specialisation of high-level specific entrepreneurial competencies and knowledge, which is very important, for example, in sales, negotiation, product development, and risk assessment (Ni \& Ye, 2018). Based on EHC theory, a person with a high level of education has high probability to become an entrepreneur (Cowling, Liu, \& Zhang, 2018). This entrepreneur will potentially combine various types of knowledge and skills in developing good products or services to meet market tastes and demands. This person will also be more observant in exploring opportunities, introducing changes, and utilising resources optimally and effectively.

Some prior studies confirmed that knowledge about entrepreneurship impacts the establishment of start-up and development of new businesses (Ni \& Ye, 2018; Farani et al., 2017; Tshikovhi \& Shambare, 2015). Furthermore, an entrepreneurial mindset is a feeling and belief in particular abilities to think out of the box (Nabi et al., 2018). Meanwhile, the self-competence of an individual is proposed by Nasrullah, Khan, and Khan (2016), which is a variable that correlates with entrepreneurial mindset. Several scholars of entrepreneurship link entrepreneurial mindset not only with self-competence but also many other factors, namely experience and confidence to act. Moreover, entrepreneurial mindset also covers personality dimension such as values, attitudes, and beliefs (Rajagopal, 2014; Solesvik et al., 2013).

Researchers believe that mindset is a holistic perception to generate new ideas, evaluate opportunities and risks, or start and run a business, which is when an individual assesses own perceptions based on holistic rather than functional attributes (Naumann, 2017; Davis \& Hall, 2015; Haynie \& Shepherd, 2007). Entrepreneurial mindset is also a way of thinking that sees opportunities not as barriers, instead seeking possibilities in failures and wanting to do something to make a difference rather than sit down and complain about problems (Walter \& Block, 2016; Haynie et al., 2010).

In the same way, Fayolle and Liñán (2014); Akmaliah et al. (2016) define entrepreneurial mindset as a particular state of mind that orients human behaviour towards entrepreneurial activities and outcomes. This implies that entrepreneurial mindset is closely related to how a person thinks (consciously or subconsciously) or his/her worldview, which influences one's tendency to be entrepreneurial. Solesvik et al. (2013) note that entrepreneurship education plays a vital role in developing and even strengthening entrepreneurial mindset. Entrepreneurship education not only provides knowledge, attitudes, and competencies but also increases motivation to develop an entrepreneurial mindset. Indeed, Haynie et al. (2010) assert that entrepreneurial mindset offers potential insight into the 
various outcomes and situations fundamental to entrepreneurial studies. Therefore, we developed the following hypotheses:

H4: Entrepreneurial knowledge positively influences entrepreneurial intention.

H5: Entrepreneurial knowledge positively influences entrepreneurial mindset.

H6: Entrepreneurial mindset positively influences entrepreneurial intention.

H7: Entrepreneurial knowledge mediates the impact of entrepreneurial education and entrepreneurial intention.

\section{RESEARCH METHODOLOGY}

The approach utilised in this study was a quantitative research design using a survey model. The major advantage of this approach is that it helps to understand how entrepreneurship education, entrepreneurial knowledge, and entrepreneurial mindset affect the intention to be an entrepreneur (Figure 1).

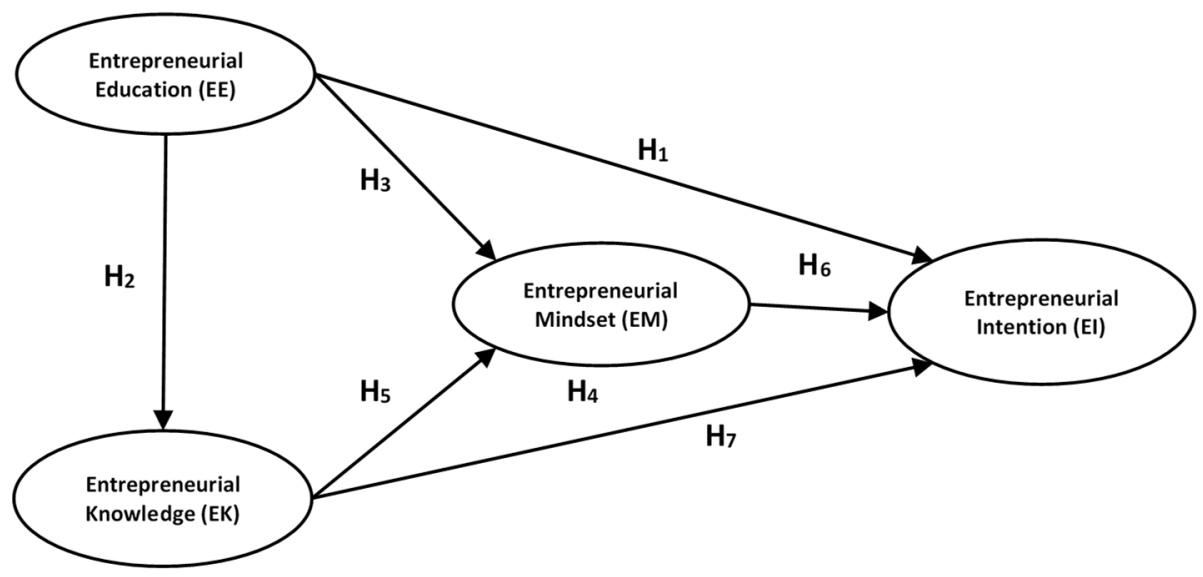

Figure 1. The research framework

Source: own elaboration based on Passoni and Glavam (2018); Barba-Sánchez and Atienza-Sahuquillo (2018); Küttim et al. (2014); Watson (2019); Fayolle and Gailly (2015); Koe (2016); Sánchez (2013); Zhang, Duysters, and Cloodt (2014).

\section{Sample and Data Collection}

The participants of this study were recruited from vocational students (SMK) in Jakarta who enrolled in the entrepreneurial education course. The focus was reasonable due to the fact that vocational schools in Jakarta are more adequate in terms of educational facilities and infrastructure than other regions of Indonesia. Thus, a convenience sample was used as is frequently done in entrepreneurship research. A total of 378 questionnaires were returned and 351 questionnaires proved useful after validation. The precise demographic of respondents is provided in Table 1.

Table 1 shows the demographic of respondents of the study. Approximately $59 \%$ of students majored in business, slightly less than a quarter majored in culinary arts, and about 
$20 \%$ majoring in marketing. Additionally, the lowest percentage of students majored in accounting. Furthermore, there were more women than men among respondents, with a percentage of approximately $56 \%$ and $44 \%$, respectively. Moreover, the majority of respondents' parents, more than a quarter was working as an entrepreneur. Accordingly, about $22 \%$ and $19 \%$ was found in the occupation of laborer and teacher/lecturer. Almost the same percentage of $9 \%$ came from government civil servant, police and soldier families.

Table 1. The demographic of respondents

\begin{tabular}{|c|c|c|c|}
\hline No. & Categories & Number of Participants & Percentage \\
\hline \multirow{4}{*}{1.} & Age & & \\
\hline & 15-years-old & 90 & 25.64 \\
\hline & 16-years-old & 180 & 51.28 \\
\hline & 17-years-old & 81 & 23.08 \\
\hline \multirow[t]{3}{*}{2.} & Gender & & \\
\hline & Female & 198 & 56.42 \\
\hline & Male & 153 & 43.58 \\
\hline \multirow[t]{5}{*}{3.} & Major & & \\
\hline & Accounting & 22 & 6.26 \\
\hline & Business & 207 & 58.97 \\
\hline & Marketing & 71 & 20.22 \\
\hline & Culinary arts & 51 & 14.55 \\
\hline \multirow[t]{7}{*}{4.} & Parents' Job & & \\
\hline & Laborer & 79 & 22.50 \\
\hline & Teacher/Lecturer & 69 & 19.65 \\
\hline & \begin{tabular}{|l|} 
Civil Servant \\
\end{tabular} & 35 & 9.97 \\
\hline & Police & 34 & 9.68 \\
\hline & Soldier & 34 & 9.68 \\
\hline & Entrepreneur & 100 & 28.52 \\
\hline
\end{tabular}

Source: own study.

\section{Instrument Development}

The questionnaires which designed to measure entrepreneurial intention (EI) was adapted from Robledo et al. (2015); Linan and Chen (2009), while to measure entrepreneurship education (EE), we adapted items from Denanyoh et al. (2015); Opoku-Antwi et al. (2012). Furthermore, to understand the entrepreneurial knowledge (EK), we adapted prior instruments validated by Al mamun et al. (2017); Kumar et al. (2018), whilst to measure entrepreneurial mindset (EM), we applied questionnaires from Mathisen and Arnulf (2013). All the items reflecting the independent and dependent variables were responded to along a 7-point Likert scale ranging from 1 indicating 'strongly disagree' to 7 indicating 'strongly agree.'

\section{Data Analysis}

We conducted two stages of testing: exploratory factor analysis and confirmatory factor analysis. Exploratory factor analysis was to validate data, explore dimensions, and maintain strong indicators (Allen, Bennett, \& King, 2010), followed by a reliability test. Statistical analysis was performed using SPSS 18. According to Hair et al. (2012), a construct can be reliable if it has a Cronbach's alpha score equal to or higher than 0.6. Secondly, this 
research followed a confirmatory factor analysis performed with AMOS 24. Schermelleh and Müller (2003) note that the model tested must have several criteria and a cut-off value, including $\mathrm{p}$-value (probability) $>0.5$, in order to obtain a fit model. Furthermore, the value of CMIN/DF < 2 (Tabachnick, Fidell, \& Ullman, 2007), CFI > 0.95, and RMSEA $\leq 0.05$ (Hu \& Bentler, 1999). Data were analysed using exploratory factor analysis (EFA), confirmatory factor analysis (CFA), and structural equation modelling (SEM).

\section{RESULTS AND DISCUSSION}

Based on the exploratory factor analysis results presented in Table 2, in total, there are 25 factors, including entrepreneurship education (6), entrepreneurial intention (6), entrepreneurial knowledge (6), and entrepreneurial mindset (7). All factors have a Cronbach's alpha ranging from 0.661 to 0.922 , which we considered sufficiently reliable to be included in further analysis. Moreover, Table 2 reveals that the value of loading for the entrepreneurial mindset (EM) variable ranged from 0.578 to 0800, with Cronbach's alpha $=0.836$. Based on the results, the EM items are considered to be reliable (Hair et al., 2012).

Table 3 provides information about the test result between variables using structural equation modelling (SEM). The SEM calculations is aimed to check the theoretical framework and fitted models. The probability score was 0.129 , the CMIN/DF score -1.241 , the CFI score -0.994 , the FMIN score -0.170 , and the RMSEA score -0.027 . From Table 3 we know that $\mathrm{H} 1, \mathrm{H} 2, \mathrm{H} 3$, and $\mathrm{H} 4$ are significant, with each C.R. score being 7.185, 9.849, 6.686 and 2.436, respectively. In contrast, $\mathrm{H} 5$ and $\mathrm{H} 6$ were not significant due to C.R. being only 1.082 and 0.835. Lastly, we learn that $\mathrm{H} 7$ is significant with b-score 2.327 (Hair et al., 2012).

Table 2. The exploratory factor analysis result

\begin{tabular}{|c|c|c|}
\hline Code & Indicator & Loadings \\
\hline & Entrepreneurial Intention & \\
\hline ei3 & I have serious doubts about ever starting my own business. & 0.900 \\
\hline ei1 & I am ready to do anything to be an entrepreneur. & 0.858 \\
\hline ei2 & I will make every effort to start and run my own business. & 0.833 \\
\hline ei4 & I am determined to create a business venture in the future. & 0.823 \\
\hline ei5 & My professional goal is to be an entrepreneur. & 0.813 \\
\hline ei6 & I have a very low intention of ever starting a business. & 0.719 \\
\hline & Entrepreneurial Education & \\
\hline ee4 & My school teaches students about entrepreneurship and starting a business. & 0.892 \\
\hline ee2 & My polytechnic provides the necessary knowledge about entrepreneurship. & 0.888 \\
\hline ee3 & My polytechnic develops my entrepreneurial skills and abilities. & 0.848 \\
\hline ee6 & I thought entrepreneurship education encourages me to be an entrepreneur. & 0.826 \\
\hline ee5 & Entrepreneurship can be developed through education. & 0.824 \\
\hline ee1 & $\begin{array}{l}\text { The education in polytechnic encourages me to develop creative ideas for being an } \\
\text { entrepreneur. }\end{array}$ & 0.819 \\
\hline ee4 & I thought entrepreneurship education encourages me to be an entrepreneur. & 0.892 \\
\hline & Entrepreneurial Knowledge & \\
\hline ek6 & I have sufficient knowledge in managing a business. & 0.842 \\
\hline ek3 & I have sufficient knowledge to organise a business. & 0.826 \\
\hline ek5 & I have sufficient knowledge in commercialising a business idea. & 0.789 \\
\hline ek4 & I have sufficient knowledge in marketing a product/service. & 0.776 \\
\hline
\end{tabular}




\begin{tabular}{|c|l|c|}
\hline Code & \multicolumn{1}{|c|}{ Indicator } & Loadings \\
\hline ek2 & I know how to find the resources (e.g. financial) to set up a business. & 0.775 \\
\hline ek1 & I have sufficient knowledge of the legal requirements to start a business. & 0.741 \\
\hline \multicolumn{1}{|c|}{$4 . \quad$ Entrepreneurial Mindset $=0.836$} \\
\hline em4 & $\begin{array}{l}|c| \\
\text { trepreneurial activities. }\end{array}$ & 0.800 \\
\hline em1 1 & $\begin{array}{l}\text { I consider both positive and negative aspects of becoming engaged in entrepre- } \\
\text { neurial activities. }\end{array}$ & 0.794 \\
\hline em5 & $\begin{array}{l}\text { I think about possible business ideas and consider becoming engaged in entrepre- } \\
\text { neurial activities. }\end{array}$ & 0.784 \\
\hline em3 & $\begin{array}{l}\text { I consider whether I have the opportunity financially to become engaged in entre- } \\
\text { preneurial activities. }\end{array}$ & 0.779 \\
\hline em2 & I consider whether I have the time to become engaged in entrepreneurial activities. & 0.726 \\
\hline em6 & $\begin{array}{l}\text { I consider whether it is desirable for me to become engaged in entrepreneurial } \\
\text { activities. }\end{array}$ & 0.633 \\
\hline em7 & $\begin{array}{l}\text { When I consider becoming engaged in entrepreneurial activities it sometimes feels } \\
\text { right and sometimes wrong. }\end{array}$ & 0.578 \\
\hline
\end{tabular}

Source: own elaboration based on Robledo et al. (2015); Linan and Chen (2009); Denanyoh et al. (2015); Opoku-Antwi et al. (2012); Al Mamun et al. (2017); Kumar et al. (2018); Mathisen and Arnulf (2013).

Table 3. The summary of testing results

\begin{tabular}{|c|c|c|c|c|c|}
\hline Hypothesis & Impact & S.E. & C.R. & $\boldsymbol{P}$ & Decision \\
\hline $\mathrm{H}_{1}$ & $\mathrm{EE} \rightarrow \mathrm{EI}$ & 0.101 & 7.185 & $* * *$ & Significant \\
\hline $\mathrm{H}_{2}$ & $\mathrm{EE} \rightarrow \mathrm{EK}$ & 0.064 & 9.849 & $* * *$ & Significant \\
\hline $\mathrm{H}_{3}$ & $\mathrm{EE} \rightarrow \mathrm{EM}$ & 0.072 & 6.686 & $* * *$ & Significant \\
\hline $\mathrm{H}_{4}$ & $\mathrm{EK} \rightarrow \mathrm{EI}$ & 0.063 & 2.436 & 0.015 & Significant \\
\hline $\mathrm{H}_{5}$ & $\mathrm{EK} \rightarrow \mathrm{EM}$ & 0.042 & 1.082 & 0.079 & Insignificant \\
\hline $\mathrm{H}_{6}$ & $\mathrm{EM} \rightarrow \mathrm{EI}$ & 0.129 & -0.835 & 0.404 & Insignificant \\
\hline $\mathrm{H}_{7}$ & \multicolumn{4}{|c|}{ Indirect $\mathrm{EE} \rightarrow \mathrm{EM} \rightarrow \mathrm{EI} \mathrm{b}=2.327$} & Significant \\
\hline
\end{tabular}

Note: $\mathrm{EE}=$ Entrepreneurial Education; $\mathrm{El}=$ Entrepreneurial Intention;

$\mathrm{EK}=$ Entrepreneurial Knowledge; $\mathrm{EM}=$ Entrepreneurial Mindset.

Source: own study.

\section{Discussion}

The study aimed at examining vocational school students' entrepreneurial intention based on entrepreneurial education courses that trained entrepreneurial education, mindset, and knowledge. Findings of this study confirm five of our hypotheses and reject two. The results indicate a positive correlation between entrepreneurship education and the intention of being an entrepreneur. Moreover, the findings agree with previous studies by Sun, Liang, and Wong (2017), Li and Wu (2019), Ferreira, Fernandes, and Ratten (2017), which reveals that entrepreneurship education promotes an individual's intention to be an entrepreneur. This finding broadly supports the work of other studies in Indonesian context, thus linking entrepreneurial education with intention (Purwana \& Suhud, 2018). The results of the study indicate that entrepreneurship education plays a crucial role in forming entrepreneurial intentions. Entrepreneurial education in vocational schools enables students to experience both theoretical and practical entrepreneurship. As the positive effect of entrepreneurship education 


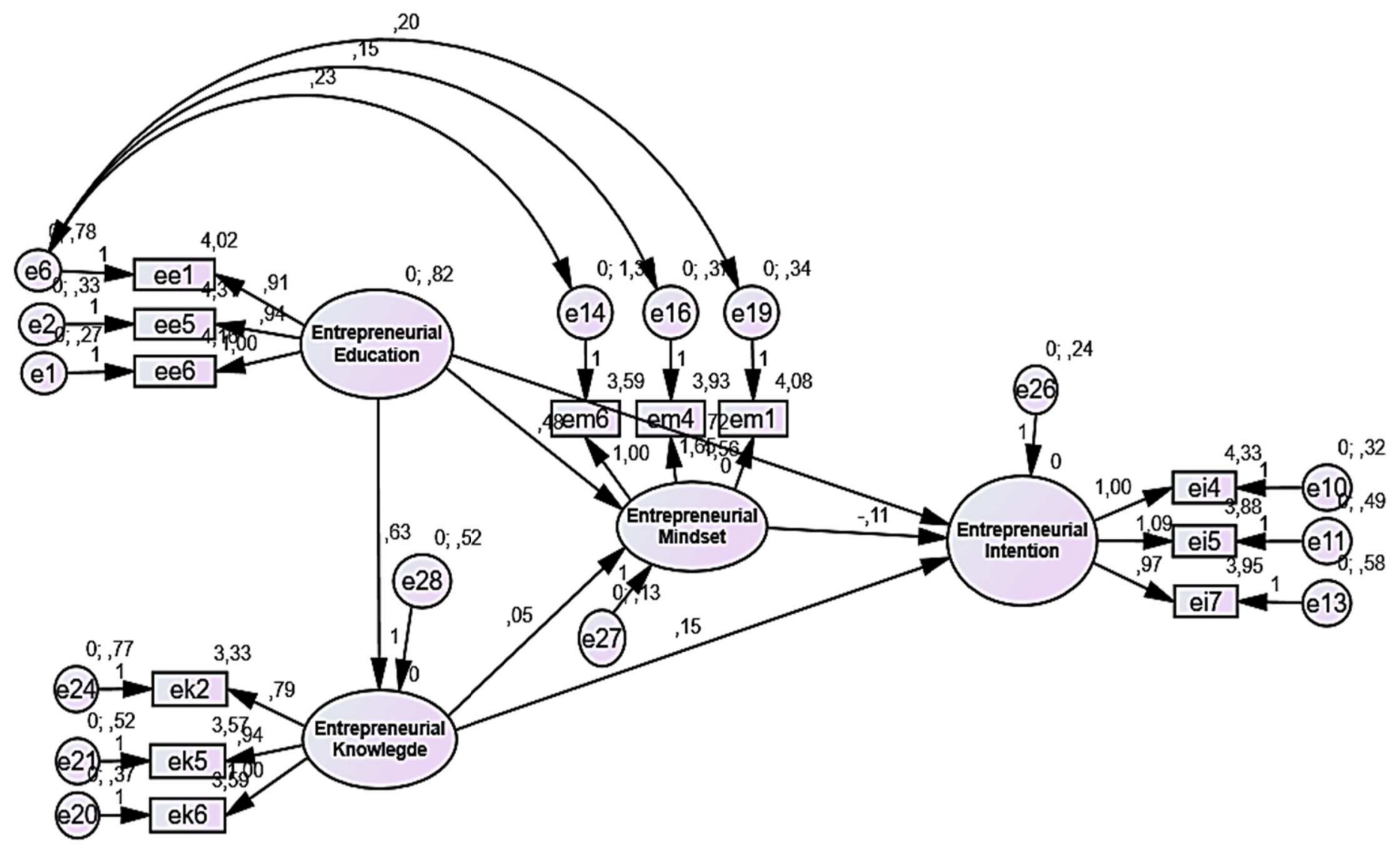

Figure 2. Results of the structural equation research model Source: own elaboration based on SEM-AMOS Output, 2020. 
motivates the Indonesian government to revitalise the curriculum and practice of entrepreneurship education, this step is expected to make effective entrepreneurship education increase young entrepreneurs' abilities through formal education.

The second question of this study sought to determine the relationship between entrepreneurial education and entrepreneurial knowledge. Increased students' knowledge as an impact of entrepreneurship education of students corroborates some earlier works. For instance, Tshikovhi and Shambare (2015), Boldureanu et al. (2020) confirm the close relationship between entrepreneurship education and entrepreneurial knowledge. Our finding implies that an individual with high-level education will potentially become an entrepreneur in the future. This entrepreneur will combine various types of knowledge and skills in developing good products or services to meet market tastes and demands. $\mathrm{S} / \mathrm{he}$ will also be more observant in exploring opportunities, introducing change, and utilising resources optimally and effectively. Similarly, Roxas (2014) argues that entrepreneurs should have the knowledge and skills that are the main capital when running a business. Our finding also supports a prior study by $\mathrm{Ni}$ and $\mathrm{Ye}$ (2018), who confirmed that entrepreneurial knowledge influenced start-up and new business development. According to Entrepreneurial Human Capital (EHC), education can increase student knowledge related to entrepreneurship. This is because the main role of entrepreneurship education is to provide students with knowledge about entrepreneurship, while its secondary role is to equip students with the skills needed in entrepreneurship.

The third finding of our study shows the significant relationship between entrepreneurship education and entrepreneurial mindset. Consistent with Hussain (2015), OpokuAntwi et al. (2012), Walter and Block (2016), Haynie et al. (2010), Zhao and Seibert (2006), we found that entrepreneurship education plays an essential role in developing and even strengthening an entrepreneurial mindset. Entrepreneurship education not only provides knowledge, attitudes, and competencies but also increases motivation to develop an entrepreneurial mindset. Similarly, our finding confirms prior studies by Solesvik et al. (2013), Haynie et al. (2010), Fayolle and Gailly (2015), who remark that the critical influence of entrepreneurship education on entrepreneurial mindset is to help an individual to focus on the right career path. An anticipated long-term investment that results from entrepreneurial knowledge is the motivation of entrepreneurial worldview which permeates one's personal, social, and professional life (Moberg, 2014).

Furthermore, our study failed in demonstrating the relationship between entrepreneurial mindset and entrepreneurial intention. This outcome is contrary to that of Hussain (2015), Opoku-Antwi et al. (2012), Walter and Block (2016), Haynie et al. (2010), and Zhao and Seibert (2006) who found a positive correlation between entrepreneurial mindset and the intention to be an entrepreneur. Our contradicting result may stem from the present curricula in entrepreneurship education at Indonesian vocational schools. Our finding could possibly be an entry point for the revitalisation of entrepreneurship education in Indonesia. It implies that even though entrepreneurship education in Indonesia influences entrepreneurial intention, it is not strong enough to encourage the actual entrepreneurial behaviour of vocational students. Thus, entrepreneurship education in the school should not only focuses on cognitive and affective aspects, but it also concerns on psychomotor domain.

The fifth question in this research was to provide the relationship between students' entrepreneurial knowledge and the intention to be an entrepreneur. This finding confirms 
hypothesis (H4). Moreover, the finding also accords with earlier observations by Rezaei Zadeh et al. (2017), and Farani et al. (2017) who showed that entrepreneurship knowledge has a positive effect on entrepreneurship intention. Prospective entrepreneurs with entrepreneurial-related knowledge - such as how to start a business, develop products, or services that can meet customer tastes and market demands - will have a high entrepreneurial intention, compared to those who do not have any at all. Furthermore, Ni and Ye (2018) argue that entrepreneurs with entrepreneurial knowledge and skills, not only witness an increase in entrepreneurial intention but also in principal capital when running their businesses.

The prior literature mentions that entrepreneurship knowledge has a positive effect on entrepreneurial mindset. However, our finding is contrary to previous studies by Rezaei Zadeh et al. (2017) and Farani et al. (2017) who suggest that entrepreneurship knowledge positively affects not only entrepreneurial intention but also entrepreneurial mindset. The difference in results stems from the inability of respondents to distinguish between entrepreneurial knowledge, entrepreneurial mindset, and entrepreneurial orientation. Moreover, our finding contrasts with the EHC theory, according to which a person with a high level of education simultaneously shows high levels of entrepreneurial mindset and entrepreneurial intention.

Lastly, our study set out with the aim of assessing the importance of entrepreneurial knowledge in mediating influences of entrepreneurship education on students' intention to be entrepreneurs. This study findings confirm the last hypothesis (H7). This result agrees with recent studies by Rezaei Zadeh et al. (2017), Farani et al. (2017), Hussain (2015), Opoku-Antwi et al. (2012), and Walter and Block (2016) who indicate that entrepreneurial education not only affects entrepreneurial knowledge but also entrepreneurial intention, both directly and indirectly. Moreover, from elementary to university levels, entrepreneurial education can play three primary roles related to the entrepreneurial mindset. First, entrepreneurial education aims to create an entrepreneurial culture that permeates all activities; second, the former is to provide special courses during which students can learn more about entrepreneurship itself. Lastly, its final role is through special training courses for individuals who want to start their own businesses (Klofsten, 2000).

\section{CONCLUSIONS}

The current article leads us to confirm five and reject two of our initial hypotheses. In more detail, the examination of entrepreneurship education impacts three variables, namely entrepreneurial mindset, entrepreneurial knowledge, and entrepreneurial intention. Moreover, the second major finding is that entrepreneurial knowledge influences students' intention to be entrepreneurs. However, entrepreneurial knowledge has an insignificant impact on entrepreneurial mindset. Lastly, our investigation of the mediating role of entrepreneurial knowledge revealed its positive influence, which implies that entrepreneurial knowledge successfully mediates entrepreneurship education and entrepreneurial intention.

These findings suggest that the Indonesian government should focus on vocational schools curricula, that could be implemented in practice instead of theory. Furthermore, the schools should provide a role model of entrepreneurs and facilitate live experience of entrepreneurship based on the model.

The most important limitation of our study lies in the fact that the data was collected in 15 vocational state schools in Jakarta, which cannot be generalised to represent real 
conditions in all vocational schools in the city. Future research should involve all vocational schools in Jakarta that would allow for the generalisation of research results.

\section{REFERENCES}

Ahmed, T., Chandran, V.G.R., Klobas, J.E., Liñán, F., \& Kokkalis, P. (2020). Entrepreneurship education programmes: How learning, inspiration and resources affect intentions for new venture creation in a developing economy. The International Journal of Management Education, 18(1), 100327. https://doi.org/10.1016/j.ijme.2019.100327

Akmaliah, Z., Pihie, L., \& Arivayagan, K. (2016). Predictors of Entrepreneurial Mindset among University Students. International Journal of Humanities, Social Sciences and Education, 3(7), 1-9. https://doi.org/10.20431/2349-0381.0307001

Al Mamun, A., Kumar, N., Ibrahim, M.D., \& Yusoff, M.N.H. (2017). Validating the Measurement of Entrepreneurial Orientation. Economics and Sociology, 10(4), 51-66. https://doi.org/10.14254/2071-789X.2017/10-4/5

Allen, P., Bennett, K., \& King, J. (2010). PASW Statistics by SPSS: A Practical Guide, Version 18. National Library of Australia.

Ana, A. Hurriyati, R., Rostika, Y., \& Nazeri, M. (2016). Entrepreneurial Intentions of Tourism Vocational High School Students in Indonesia and Malaysia. Journal of Technical Education and Training (JTET), 8(2), 12-20.

Backström-Widjeskog, B. (2010). Creativity and Innovation - Preconditions for entrepreneurial education Eds. Kjell Skogen and Jarle Sjøvoll (2010) Trondheim: Tapir Academic Press Teachers' thoughts on entrepreneurship education. 8, 107-120.

Boldureanu, G., lonescu, A.M., Bercu, A., Bedrule-Gregoruta, M.V., \& Boldureanu, D. (2020). Entrepreneurship Education Through Entrepreneurial Model in Higher Education Institutions. Sustainability, 12, 1267. https://doi.org/10.3390/su12031267

BPS. (2019). Keadaan Ketenagakerjaan Indonesia Agustus 2019. Badan Pusat Statistik.

Barba-Sánchez, V., \& Atienza-Sahuquillo, C. (2018). Entrepreneurial intention among engineering students: The role of entrepreneurship education. European Research on Management and Business Economics, 24(1), 53-61. https://doi.org/10.1016/j.iedeen.2017.04.001

Bergmann, H. (2017). The formation of opportunity beliefs among university entrepreneurs: an empirical study of research-and non-research-driven venture ideas. The Journal of Technology Transfer, 42(1), 116-140. https://doi.org/10.1007/s10961-015-9458-z

Cowling, M., Liu, W., \& Zhang, N. (2018). Did firm age, experience, and access to finance count? SME performance after the global financial crisis. Journal of Evolutionary Economics, 28(1), 77-100. https://doi.org/10.3390/su12031267

Davis, M.H., \& Hall, J.A. (2015). Developing a New Measure of Entrepreneurial Mindset: Reliability, Validity, and ... Consulting Psychology Journal: Practice and. (December). https://doi.org/10.1037/cpb0000045

Denanyoh, R., Adjei, K., \& Nyemekye, G.E. (2015). Factors that impact on entrepreneurial intention of tertiary students in Ghana. International Journal of Business and Social Research, 5(3), 19-29.

do Paco, A., Ferreira, J.M., Raposo, M., Rodrigues, R.G., \& Dinis, A. (2013). Entrepreneurial intentions: is education enough?. International Entrepreneurship and Management Journal. https://doi.org/10.1007/s11365-013-0280-5 
Dvoulety, O., Mühlböck, M., Warmuth, J., \& Kittel, B. (2018). 'Scarred' young entrepreneurs. Exploring young adults' transition from former unemployment to self-employment. Journal of Youth Studies, 21(9), 1159-1181. https://doi.org/10.1080/13676261.2018.1450971

Farani, A.Y., Karimi, S., \& Motaghed, M. (2017). The role of entrepreneurial knowledge as a competence in shaping Iranian students' career intentions to start a new digital business. European Journal of Training and Development, 41(1), 83-100. https://doi.org/10.1108/EJTD-07-2016-0054

Eryanto, H., Swaramarinda, D.R., \& Nurmalasari, D. (2019). Effectiveness of entrepreneurship practice program: Using cipp program evaluation. Journal of Entrepreneurship Education, 22(1), 1-10.

Fayolle, A. (2006). Assessing the impact of entrepreneurship education programmes: a new methodology. 30(9), 701-720. https://doi.org/10.1108/03090590610715022

Fayolle, A., \& Gailly, B. (2015). The impact of entrepreneurship education on entrepreneurial attitudes and intention: Hysteresis and persistence. Journal of Small Business Management, 53(1), 75-93. https://doi.org/10.1111/jsbm.12065

Fayolle, A., \& Liñán, F. (2014). The future of research on entrepreneurial intentions. Journal of Business Research, 67(5), 663-666. https://doi.org/10.1016/j.jbusres.2013.11.024

Ferreira, J.J., Fernandes, C.I., \& Ratten, V. (2017). The influence of entrepreneurship education on entrepreneurial intentions. In Entrepreneurial universities (pp. 19-34). Cham: Springe.

George, G., \& Bock, A.J. (2011). The Business Model in Practice and its Implications for Entrepreneurship Research. Entrepreneurship: Theory and Practice. https://doi.org/10.1111/j.15406520.2010.00424.x

Hair, J.F., Ringle, C.M., \& Sarstedt, M. (2012). Partial least squares: the better approach to structural equation modeling?. Long Range Planning, 45(5-6), 312-319.

Hani, U., Rachmania, I.N., Setyaningsih, S., \& Putri, R.C. (2012). Patterns of Indonesian Women Entrepreneurship. Procedia Economics and Finance. https://doi.org/10.1016/s22125671(12)00342-5

Haynie, J.M., \& Shepherd, D.A. (2007). Exploring the entrepreneurial mindset: Feedback and adaptive decision-making. Frontiers of Entrepreneurship Research, 27(6), 1-15.

Haynie, J.M., Shepherd, D., Mosakowski, E., \& Earley, P.C. (2010). A situated metacognitive model of the entrepreneurial mindset. Journal of Business Venturing, 25(2), 217-229. https://doi.org/10.1016/j.jbusvent.2008.10.001

Hu, L.T., \& Bentler, P.M. (1999). Cut-off Criteria for Fit Indexes in Covariance Structure Analysis: Conventional Criteria Versus New Alternatives. Structural Equation Modelling: A Multidisciplinary Journal, 6(1), 1-55.

Hussain, A., \& Norashidah, D. (2015). Impact of Entrepreneurial Education and Entrepreneurial Intention of Pakistani Students. Journal of Entrepreneurship and Business Innovation, 2(1), 43-53. https://doi.org/10.5296/jebi.v2i1.7534

Jabeen, F., Faisal, M.N., \& Katsioloudes, M.I. (2017). Entrepreneurial mindset and the role of universities as strategic drivers of entrepreneurship. Journal of Small Business and Enterprise Development, 24(1), 136-157. https://doi.org/10.1108/JSBED-07-2016-0117

Jena, R.K. (2020). Measuring the impact of business management Student's attitude towards entrepreneurship education on entrepreneurial intention: A case study. Computers in Human Behavior, 107, 106275. https://doi.org/10.1016/j.chb.2020.106275

Kim, M., \& Park, M.J. (2019). Entrepreneurial education program motivations in shaping engineering students' entrepreneurial intention. Journal of Entrepreneurship in Emerging Economies, 11 (3), 328-350. https://doi.org/10.1108/JEEE-08-2018-0082 
Koe, W.-L. (2016). The relationship between Individual Entrepreneurial Orientation (IEO) and entrepreneurial intention. Journal of Global Entrepreneurship Research. https://doi.org/10.1186/s40497-016-0057-8

Kumar, N., Al Mamun, A., Ibrahim, M.D., \& Yusoff, N.H. (2018). Entrepreneurial Orientation and Antecedents of Low-Income Household Heads in Kelantan, Malaysia. Journal of International Studies, 11(1), 140-151. https:/doi.org/10.1425/2071-8330.2017/11-1/10

Kuttim, M., Kallaste, M., Venesaar, U., \& Kiis, A. (2014). Entrepreneurship Education at University Level and Students' Entrepreneurial Intentions. Procedia - Social and Behavioral Sciences, 110, 658-668. https://doi.org/10.1016/j.sbspro.2013.12.910

Lackeus, M. (2014). An Emotion Based Approach to Assessing Entrepreneurial Education. The International Journal of Management Education, 12(3), 374-396. https://doi.org/10.1016/j.jjme.2014.06.005

Li, L., \& Wu, D. (2019). Entrepreneurial education and students' entrepreneurial intention: does team cooperation matter?. Journal of Global Entrepreneurship Research, 9(1), 35. https://doi.org/10.1186/s40497-019-0157-3

Linan, F., \& Chen, Y.W. (2009). Development and Cross-Cultural Application of A Specific Instrument to Measure Entrepreneurial Intention. Entrepreneurship Theory and Practice, 33(3), 593-617. https://doi.org/10.1111\%2Fj.1540-6520.2009.00318.x

Mathisen, J.E., \& Arnulf, J.K. (2013). Competing Mindsets in Entrepreneurship: The Cost of Doubt. The International Journal of Management Education, 11(3), 132-141. https://doi.org/10.1016/j.ijme.2013.03.003

Minola, T., Criaco, G., \& Cassia, L. (2014). Are youth really different? New beliefs for old practices in entrepreneurship. Int. J. Entrepreneurship and Innovation Management, 18(2/3), 233-259.

Moberg, K. (2014). Two approaches to entrepreneurship education: The different effects of education for and through entrepreneurship at the lower secondary level. The International Journal of Management Education, 12(3), 512-528. https://doi.org/10.1016/j.ijme.2014.05.002

Nabi, G., Linan, F., Fayolle, A., Krueger, N., \& Walmsley, A. (2018). The impact of entrepreneurship education in higher education: A systematic review and research agenda. Academy of Management Learning and Education, 16, 277-299. https://doi.org/10.5465/amle.2015.0026

Nasrullah, S., Khan, M.S., \& Khan, I. (2016). The Entrepreneurship Education and Academic Performance. Journal of Education and Practice, 7(1), 1-4.

Naumann, C. (2017). Entrepreneurial Mindset: A Synthetic Literature Review. Entrepreneurial Business and Economics Review, 5(3), 149-172. https://doi.org/10.15678/eber.2017.050308

Ni, H., \& Ye, Y. (2018). Entrepreneurship Education Matters: Exploring Secondary Vocational School Students' Entrepreneurial Intention in China. Asia-Pacific Education Researcher, 27(5), 409-418. https://doi.org/10.1007/s40299-018-0399-9

Passoni, D., \& Glavam, R.B. (2018). Entrepreneurial intention and the effects of entrepreneurial education. International Journal of Innovation Science, 10(1), 92-107. https://doi.org/10.1108/IJIS-05-2017-0042

Purwana, D., Sadat, A.M., \& Wibowo, A. (2019). A Comparative Study of Tertiary Student's Entrepreneurial Intention: Indonesia and Taiwan. International Journal of Entrepreneurship, 23(4), 1-9.

Purwana, D., \& Suhud, U. (2018). Investigating the effect of motivation on entrepreneurial intention: Three different approaches. Problems and Perspectives in Management, 16(2), 200-208. https://doi.org/10.21511/ppm.16(2).2018.18

Rajagopal. (2014). The Entrepreneurial Mindset. In Architecting Enterprise. https://doi.org/10.1057/9781137366788_2 
Rauch, A., \& Hulsink, W. (2015). Putting entrepreneurship Education where the intention to Act lies: An investigation into the impact of entrepreneurship education on entrepreneurial behavior. Academy of management learning \& education, 14(2), 187-204. https://doi.org/10.5465/amle.2012.02

Robledo, J.L.R., Aran, M.V., Sanchez, V.M., \& Molina, M.A.R. (2015). The moderating Role of Gender on Entrepreneurial Intentions: A TPB Perspective. Intangiable Capital, 11(1), 92-117. https://doi.org/10.3926/ic.557

Roxas, B. (2014). Effects of Entrepreneurial Knowledge on Entrepreneurial Intention: A Longitudinal Study of Selected South-East Asian Business Studies. Journal of Education and Work, 27(4), 432453. https://doi.org/10.1080/13639080.2012.760191

Saeed, S., Yousafzai, S.Y., Yani-De-Soriano, M., \& Muffatto, M. (2015). The role of perceived university support in the formation of students' entrepreneurial intention. Journal of Small Business Management, 53(4), 1127-1145. https://doi.org/10.1111/jsbm.12090

Sánchez, J.C. (2013). The impact of an entrepreneurship education program on entrepreneurial competencies and intention. Journal of Small Business Management, 51(3), 447-465. https://doi.org/10.1111/jsbm.12025

Saptono, A., \& Wibowo, A. (2018). Do Learning Environment and Self-Efficacy Impact on Student's Entrepreneurial Attitude?. International Journal of Entrepreneurship, 22(4), 1-11.

Saptono, A., Purwana, D., Wibowo, A., Wibowo, S.F., Mukhtar, S., Yanto, H., ... Kusumajanto, D.D. (2019). Assessing the university students' entrepreneurial intention: Entrepreneurial education and creativity. Humanities and Social Sciences Reviews, 7(1), 505-514. https://doi.org/10.18510/hssr.2019.7158

Schermelleh-Engel, K., Moosbrugger, H., \& Müller, H. (2003). Evaluating the fit of structural equation models: Tests of significance and descriptive goodness-of-fit measures. Methods of psychological research online, 8(2), 23-74.

Sendouwa, R.H.E., Lonto, A.L., \& Saroinsong, S.J.R. (2019). Entrepreneurship development program in the higher education in Indonesia. International Journal of Recent Technology and Engineering. https://doi.org/10.35940/ijrte.B1022.0982S919

Solesvik, M.Z., Westhead, P., Matlay, H., \& Parsyak, V.N. (2013). Entrepreneurial assets and mindsets: Benefit from university entrepreneurship education investment. Education + Training, 55, 748-762. https://doi.org/10.1108/ET-06-2013-0075

Souitaris, V., Zerbinati, S., \& Al-Laham, A. (2007). Do entrepreneurship programmes raise entrepreneurial intention of science and engineering students? The effect of learning, inspiration and resources. Journal of Business Venturing. https://doi.org/10.1016/j.jbusvent.2006.05.002

Sun, H., Lo, C.T., Liang, B., \& Wong, Y.L.B. (2017). The impact of entrepreneurial education on entrepreneurial intention of engineering students in Hong Kong. Management Decision, 55(7), 13711393. https://doi.org/10.1108/MD-06-2016-0392

Suparno, S., Wibowo, A., Mukhtar, S., Narmaditya, B.S., \& Sinta, H.D. (2019). The Determinant Factors of Development Batik Cluster Business: Lesson from Pekalongan, Indonesia. The Journal of Asian Finance, Economics and Business, 6(4), 227-233. https://doi.org/10.13106/jafeb.2019.vol6.no4.227

Tabachnick, B.G., Fidell, L.S., \& Ullman, J.B. (2007). Using Multivariate Statistics (Vol.5, pp. 481-498). Boston: MA: Pearson.

Tshikovhi, N., \& Shambare, R. (2015). Entrepreneurial Knowledge, Personal Attitudes, and Entrepreneurship Intentions Among South African Enactus Students. Problems and Perspectives in Management, 13(1), 152-158. 
Utami, C.W. (2017). Attitude, Subjective Norms, Perceived behavior, Entrepreneurship education and Self-efficacy toward entrepreneurial intention University student in Indonesia. European Research Studies Journal, 20(2), 475-495.

Utomo, H., Priyanto, S.H., Suharti, L., \& Sasongko, G. (2019). Developing social entrepreneurship: A study of community perception in Indonesia. Entrepreneurship and Sustainability Issues, 7(1), 233-246. https://doi.org/10.9770/jesi.2019.7.1(18)

Van Gelderen, M., Kautonen, T., \& Fink, M. (2015). From entrepreneurial intentions to actions: Selfcontrol and action-related doubt, fear, and aversion. Journal of Business Venturing, 30(5), 655673. https://doi.org/10.1016/j.jbusvent.2015.01.003

Walter, S.G., \& Block, J.H. (2016). Outcomes of entrepreneurship education: An institutional perspective. Journal of Business Venturing, 31(2), 216-233. https://doi.org/10.1016/j.jbusvent.2015.10.003

Watson, K. (2019). Stimulating entrepreneurial behaviour through start-up competitions: current features of provision in UK higher education institutions. In Entrepreneurial Behaviour (pp. 121143). Cham: Palgrave Macmillan.

Wibowo, A., Saptono, A., \& Suparno (2018). Does teachers' creativity impact on vocational students' entrepreneurial intention?. Journal of Entrepreneurship Education, 21(3).

Wibowo, S.F., Purwana, D., Wibowo, A., \& Saptono, A. (2019). Determinants of entrepreneurial intention among millennial generation in emerging countries. International Journal of Entrepreneurship, 23(2), 1-10.

Winarno, A. (2016). Entrepreneurship Education in Vocational Schools: Characteristics of Teachers, Schools and Risk Implementation of the Curriculum 2013 in Indonesia. Journal of Education and Practice.

Solesvik, Z.M., Westhead, P., Matlay, H., \& N. Parsyak, V. (2013). Entrepreneurial assets and mindsets. Education + Training. https://doi.org/10.1108/et-06-2013-0075

Zhang, Y., Duysters, G., \& Cloodt, M. (2014). The role of entrepreneurship education as a predictor of university students' entrepreneurial intention. International Entrepreneurship and Management Journal, 10(3). https://doi.org/10.1007/s11365-012-0246-z

Zhao, H., \& Seibert, S.E. (2006). The big five personality dimensions and entrepreneurial status: A meta-analytical review. Journal of Applied Psychology, 91(2), 259-271. https://doi.org/10.1037/0021-9010.91.2.259 


\section{Authors}

The share of each authors is as follows: Ponco Dewi Karyaningsih 40\%, Agus Wibowo 20\%, Ari Saptono 20\%, Bagus Shandy Narmaditya 20\%. Karyaningsih and Saptono devised the project and outlined the main conceptual ideas. Wibowo and Narmaditya provided technical details and performed the study. Wibowo and Karyaningsih wrote the entire paper, then Narmaditya and Saptono translated it and proofread.

\section{Ponco Dewi Karyaningsih}

Associate Professor at the Faculty of Economics of Universitas Negeri Jakarta, Indonesia. He teaches courses on entrepreneurship and education. Research interests: entrepreneurship education and education.

Correspondence to: $\mathrm{Rr}$ Ponco Dewi Karyaningsih, Faculty of Economics, Universitas Negeri Jakarta, Jalan Rawamangun Muka, Jakarta Timur, 13220, Indonesia, e-mail: poncodewi@unj.ac.id ORCID (1) http://orcid.org/0000-0003-4302-3264

\section{Agus Wibowo}

Assistant Professor of entrepreneurship at the Faculty of Economics of Universitas Negeri Jakarta, Indonesia. He is a doctoral candidate in Economic Education at Universitas Negeri Malang. He is an editor and reviewer in several social sciences journals. Research interests: entrepreneurship; entrepreneurship education; education.

Correspondence to: Agus Wibowo, Faculty of Economics, Universitas Negeri Jakarta, Jalan Rawamangun Muka, Jakarta Timur, 13220, Indonesia, e-mail: agus-wibowo@unj.ac.id ORCID (1) http://orcid.org/0000-0003-0051-1743

\section{Ari Saptono}

Associate Professor of educational assessment at the Faculty of Economics at Universitas Negeri Jakarta, Indonesia. He teaches economics education and educational assessment entrepreneurship. Research interests: entrepreneurship education; entrepreneurship; educational assessment.

Correspondence to: Ari Saptono, Faculty of Economics, Universitas Negeri Jakarta, Jalan Rawamangun Muka, Jakarta Timur, 13220, Indonesia, e-mail: saptono.fe@unj.ac.id ORCID (1) http://orcid.org/0000-0002-4182-2284

\section{Bagus Shandy Narmaditya}

Lecturer at the Faculty of Economics, Universitas Negeri Malang, Indonesia. He graduated from the Economic Education Program at Universitas Negeri Malang. His research focus is economic education, entrepreneurship education, and economic welfare. He participated at the GSE summer school at Universitat Pompeu Fabra Barcelona, Spain. He also actively participated in international conferences in various countries such as Indonesia, Thailand, Vietnam, Hongkong, and Japan.

Correspondence to: Bagus Shandy Narmaditya, Faculty of Economics, Universitas Negeri Malang, Jalan Semarang 5 Malang, 65145, Indonesia, e-mail: bagus.shandy.fe@um.ac.id ORCID (1) http://orcid.org/0000-0002-4019-8723

\section{Acknowledgements and Financial Disclosure}

The authors would like to thank the anonymous referees for their useful comments, which allowed for the increase of the value of this article. The authors would also thanks to the Faculty of Economics at Universitas Negeri Jakarta for the valuable support of this research through young lecturers scheme in 2020. 


\section{Copyright and License}

(c) (1) $\Theta$

This article is published under the terms of the Creative Commons

Attribution - NoDerivs (CC BY-ND 4.0) License

http://creativecommons.org/licenses/by-nd/4.0/

Published by Cracow University of Economics - Krakow, Poland

The copyediting and proofreading of articles in English is financed in the framework and Higher Education of contract No. 913/P-DUN/2019 by the Ministry of Science and Higher Education Republic of Poland $\quad$ of the Republic of Poland committed to activities aimed at science promotion. 
